\title{
KEKUATAN MENGIKAT PUTUSAN CONSTITUTIONAL REVIEW MAHKAMAH KONSTITUSI TERHADAP MAHKAMAH AGUNG*
}

\author{
Rian Van Frits Kapitan \\ Program Pascasarjana Universitas Nusa Cendana \\ Jl. Adi Sucipto Penfui - Kota Kupang, 85001 \\ email:ryankapitan@ymail.com
}

\begin{abstract}
The Existence of Supreme Court ruling that punishes dr. Bambang suprapto.Sp.M.Surg. using article 76 of law no 29 of 2004 on medical practices that had previously been cancelled by the Constitutional Court itself has proved that the Supreme Court has ruled constitutional the constitutional court's decision. This paper attempts to justify that by reason of any Constitutional Court still has binding force for the Supreme Court. It is based on four perspectives namely: 1. Historical perspective 2. Perspective protected object 3. Perspective functional 4. And normative perspectiv
\end{abstract}

Keywords: Binding Force,Constitutional Review,Constitutional Court, Supreme Court

\section{Abstrak}

Adanya putusan Mahkamah Agung yang menghukum dr. Bambang Suprapto, Sp.M.Surg mengunakan Pasal 76 Undang-Undang Nomor 29 Tahun 2004 tentang Praktek Kedokteran yang sebelumnya telah dibatalkan oleh Mahkamah Konstitusi dengan sendirinya telah membuktikan bahwa Mahkamah Agung telah mengesampingkan putusan constitutional review Mahkamah Konstitusi. Tulisan ini mencoba untuk menjustifikasi bahwa dengan alasan apapun putusan constitutional review Mahkamah Konstitusi tetap mempunyai kekuatan mengikat bagi Mahkamah Agung. Hal ini didasarkan atas empat perspektif, yaitu : 1.perspektif historis, 2.perspektif objek yang dilindungi, 3.perspektif fungsional, dan 4.perspektif normatif.

Kata Kunci: Kekuatan Mengikat, Constitutional Review, Mahkamah Konstitusi, Mahkamah Agung

\section{A. Pendahuluan}

\section{Latar Belakang}

Secara konstitusional kewenangan

Mahkamah Konstitusi Indonesia mengenai constitutional review diatur dalam Pasal 24C Ayat (1) UUDNRI Tahun 1945 yang secara tegas ditentukan : Mahkamah Konstitusi berwenang dan putusannya bersifat final untuk menguji Undang-undang terhadap Undang-Undang Dasar, memutus sengketa kewenangan antar lembaga negara yang kewenangannya diberikan oleh UndangUndang Dasar, memutus pembubaran partai politik, dan memutus perselisihan hasil pemilihan umum.

Berdasarkan Pasal 24C Ayat (1) UUDNRI 1945 tersebut dapat dilihat bahwa kewenangan untuk melakukan constitutional review ditegaskan pada poin pertama. Hal ini mengandung arti bahwa kewenangan Mahkamah Konstitusi zyang paling utama ialah melakukan constitutional review.

Terdapat satu hal istimewa dari lembaga ini, yaitu putusan Mahkamah Konstitusi mempunyai sifat final dan mengikat. Dikatakan final karena terhadap putusan tersebut tidak dapat lagi dilakukan upaya hukum dan dikatakan mengikat karena

\footnotetext{
* Sebagian besar isi dari tulisan ini merupakan Tesis penulis pada Program Pascasarjana Program Studi Ilmu Hukum Universitas Nusa Cedana Kupang, Tahun 2015 yang berjudul "Kekuatan Mengikat Putusan Constitutional Review Mahkamah Konstitusi Terhadap Mahkamah Agung"

1. Lihat Pasal 24C Ayat (1)UUD NRI Tahun 1945
} 
putusan Mahkamah Konstitusi tersebut seketika dibacakan di hadapan sidang yang terbuka untuk umum, maka langsung mempunyai kekuatan hukum mengikat bagi seluruh subjek hukum dalam yuridiksi NKRI.

Tampak bahwa dengan sifat putusan yang demikian, maka putusan Mahkamah Konstitusi dalam perkara constitutional review secara normatif dan praktis mempunyai kekuatan yang setara dengan Undang-undang, namun dalam kenyataannya terdapat putusan Mahkamah Konstitusi dalam perkara constitutional review yang tidak mempunyai kekuatan mengikat bagi lembaga negara lain yang dalam hal ini ialah Mahkamah Agung Republik Indonesia. Katakan saja Putusan Mahkamah Agung dalam tingkat kasasi ( Putusan MA RI Nomor. 1110 K/Pid.Sus/2012 ) dengan terdakwa dr. Bambang Suprapto, Sp.M.Surg. Dalam putusan ini dr. Bambang Suprapto, Sp.M.Surg, dihukum oleh Mahkamah Agung menggunakan ancaman pidana penjara dalam Pasal 76 Undang-undang Nomor 29 Tahun 2004 tentang Praktek Kedokteran yang sebelumnya telah dibatalkan oleh Mahkamah Konstitusi ( Putusan MK RI Nomor. 4/PUUV/2007 ), sehingga sontak saja mantan Ketua Mahkamah Konstitusi Jimmly Assheddiqqie berkomentar di media massa bahwa Majelis Hakim Agung (diketuai oleh Hakim Agung Artidjo Alkostar) yang memvonis dr. Bambang memakai ancaman pidana yang telah dibatalkan Mahkamah Konstitusi tersebut adalah "Hakim- tolol dan bodoh". ${ }^{2}$

\section{Metode Penelitan}

Berdasarkan substansi permasalahan atau isu hukum yang dikaji dalam penelitian ini, maka penelitian ini merupakan penelitian hukum doktrinal/normatif. Karakteristik penelitan ini adalah menyusun konsepkonsep, asas-asas dan ketentuan-ketentuan hukum yang berkaitan dengan kekuatan mengikat putusan constitutional review Mahkamah Konstitusi terhadap Mahkamah Agung. Kemudian pendekatan yang digunakan dalam penelitian ini adalah pendekatan perundang-undangan (statutaapproach), pendekatan konseptual (conceptual approach), dan pendekatan historis (historicalapproach)

\section{Kerangka Teori}

a.Kedudukan dan Kewenangan Mahkamah Agung dan Mahkamah Konstitusi Menurut UUDNRI Tahun 1945.

1) Kedudukan dan Kewenangan Mahkamah Agung Menurut UUD 1945.

Amandemen Undang-Undang Dasar 1945 telah menempatkan Mahkamah Agung tidak lagi sebagai satu satunya pelaku kekuasaan Kehakiman tetapi Mahkamah Agung hanya salah satu pelaku kekuasaan kehakiman. UUDNRI Tahun 1945 menentukan bahwa Mahkamah Agung dan badan peradilan yang berada di bawahnya dalam lingkungan peradilan umum, lingkungan peradilan agama, lingkungan peradilan militer, lingkungan peradilan tata usaha negara adalah pelaku kekuasaan kehakiman yang merdeka, disamping Mahkamah Konstitusi. Kedudukan Mahkamah Agung tersebut dapat dilihat pada Pasal 24 Ayat (2) UUDNRI Tahun 1945 yang menyatakan bahwa : "Kekuasaan kehakiman dilakukan oleh sebuah Mahkamah Agung dan badan peradilan yang berada di bawahnya dalam lingkungan peradilan umum, lingkungan peradilan agama, lingkungan peradilan militer, lingkungan peradilan tata usaha negara, dan oleh sebuah Mahkamah Konsitisi”.

Mengenai kewenangan Mahkamah Agung setelah UUD 1945 diamandemen ditegaskan dalam Pasal 24A Ayat (1) UUD NRI Tahun 1945 yang berbunyi :

(1) Mahkamah Agung berwenang mengadili pada tingkat kasasi, menguji peraturan perundang-undangan di bawah undangundang terhadap undang-undang, dan mempunyai wewenang lainnya yang diberikan oleh undang-undang.

Kewenangan Mahkamah Agung yang

2. http://news.detik.com/read/2014/09/26/084623/2701838/158/1/kasus-dr-bambang-mantan-ketua-mk-emangnya-artidjo-pasti baik, diakses pada tanggal 02 Maret 2015. 
pertama tersebut sejalan dengan apa yang dikemukakan oleh R. Subekti. ${ }^{3}$ Beliau menyatakan bahwa Mahkamah Agung sebagai pengadilan Tertinggi merupakan pengadilan KASASI, yang tugasnya adalah membina keseragaman dalam penerapan hukum dan menjaga agar semua hukum dan undang-undang di seluruh wilayah Negara diterapkan secara tepat dan adil.

\section{2) Kedudukan dan Kewenangan Mahkamah Konstitusi Menurut UUDNRI Tahun 1945.}

Berdasarkan Pasal 24 Ayat (1) UUDNRI Tahun 1945 kekuasaan kehakiman merupakan kekuasaan yang merdeka untuk menyelenggarakan peradilan guna menegakan hukum dan keadilan. Kekuasaan kehakiman dilaksanakan oleh Mahkamah Agung dan badan peradilan di bawahnya dan oleh sebuah Mahkamah Konstitusi (Pasal 24 Ayat (2) UUDNRI Tahun 1945). Dengan demikian kedudukan Mahkamah Konstitusi dalam UUDNRI Tahun 1945 adalah sebagai salah satu pelaku kekuasaan kehakiman yang sejajar kedudukannya dengan Mahkamah Agung.

Selanjutnya kewenangan Mahkamah Konstitusi ditegaskan dalam Pasal 24C Ayat (1) UUDNRI Tahun 1945 hasil amandemen yang menyatakan bahwa: "Mahkamah Konstitusi berwenang mengadili pada tingkat pertama dan terakhir yang putusannya bersifat final untuk menguji undang-undang terhadap Undang-Undang Dasar, memutus sengketa kewenangan lembaga negarayang kewenangaanya diberikan oleh UndangUndang Dasar, memutus pembubaran partai politik, dan memutus perselisihan tentang hasil pemilihan umum."

Kewenangan Mahkamah Konstitusi untuk melakukan pengujian undang-undang terhadap UUD tersebut sebenarnya merupakan kewenangan paling utama dari Mahkamah Konstitusi. Kewenangan ini disebut dengan istilah "Constitutional review" 4

\section{b. Gagasan Constitutional Review dan Pelembagaan Mahkamah Konstitusi di Indonesia.}

Secara umum konsep constitutional review mengemuka dari konsep judicial review di Amerika Serikat. Walaupun sekilas keduanya tampak memiliki kesamaan, namun terdapat perbedaan. Constitusional review ialah pengujian norma hukum terhadap UUD. Biasanya pengujian tersebut selain dapat dilakukan oleh lembaga peradilan dapat juga dilakukan oleh lembaga lain.

Kemudian jikalau berbicara mengenai judicial review, maka yang terbesit dibenak orang pastilah pengujian norma hukum terhadap UUD oleh lembaga peradilan. Konsep yang seperti ini jelas tidak salah, sebab judicial review memang pengujian norma hukum terhadap UUD oleh lembaga peradilan. Kalau demikian jawabannya, maka apa bedanya dengan constitusional review ? Bedanya ialah judicial review hanyalah dilakukan oleh lembaga peradilan dan bukan oleh lembaga lain seperti layaknya constitusional review. Lalu, judicial review juga lebih luas cakupannya karena selain menguji norma hukum terhadap UUD juga menguji pertentangan antara norma hukum yang tersebar di berbagai peraturan perundang-undangan di bawah UUD. Contohnya Mahkamah Agung Indonesia yang berwenang menguji Peraturan perundangundangan di bawah Undang-undang terhadap Undang-undang.

Mendukung argumentasi di atas, maka penulis mengutip apa yang dikatakan oleh Jimly Asshiddiqie dalam Ni'matul Huda dan Nazriyah bahwa : Istilah "Constitutional review" atau pengujian konstitusional harus dibedakan dengan istilah "Judicial review". Pembedaan itu dilakukan sekurangkurangnya karena dua alasan. Pertama, "Constitutional review" selain dilakukan oleh hakim dapat pula dilakukan oleh lembaga selain hakim atau pengadilan, tergantung kepada lembaga mana UUD memberikan kewenangan untuk melakukannya. Kedua, dalam konsep "Judicial review" terkait pula pengertian yang lebih luas objeknya, misalnya

3. R Subekti, 1980, Kekuasaan Mahkamah Agung RI, Bandung, Alumni, hlm 1-2.

4. Lihat Moh Mahfud MD, 2010, Konstitusi Dan Hukum Dalam Kontroversi Isu, Jakarta, Rajawali Pers, hlm 64. 
mencakup soal legalitas peraturan di bawah UU terhadap UU, sedangkan "Constitutional review" hanya menyangkut pengujian konstitusionalitas, yaitu terhadap UUD. ${ }^{5}$

Telah diulas di atas bahwa konsep constitutional review mengemuka dari konsep judicial review di Amerika Serikat. Hal ini diprakarsai oleh Ketua Mahkamah Agung Amerika Serikat yang bernama John Marshall yang kala itu membatalkan Judiciary Act 1789 karena isinya dianggapbertentangan dengan Konstitusi Amerika Serikat.

Peristiwa yang terjadi di Amerika Serikat tersebut kemudian memotivasi George Jellinek untuk mengembangkan kewenangan Mahkamah Agung Austria. Saat itu, Mahkamah Agung Austria sudah mempunyai wewenang untuk mengadili sengketa antara warga negara dan pemerintah terkait dengan perlindungan hak politik, bahkan pengadilan negara bagian telah memiliki wewenang untuk memutus keberatan konstitusional yang diajukan warga negara atas tindakan pemerintah.

Perkembangan selanjutnya tentang pengujian konstitusional terjadi pada tahun 1919-1920, yaitu pada saat diadakannya pembaruan Konstitusi Austria. Salah satu anggota Chancelery (tim pembaharu konstitusi Austria)yang bernama Hans Kelsen mengemukakan usul agar dibentuknya sebuah Mahkamah Konstitusi (lembaga peradilan di luar Mahkamah Agung yang khusus menangani perkara konstitusional) dan pada akhrinya usul itu diterima menjadi salah satu substansi dari Konstitusi Austria. ${ }^{6}$

Mahkamah Konstitusi gagasan Hans Kelsen di Austria tersebut akhirnya diadopsi pertama kali oleh Cekoslowakia, sehingga walaupun gagasan Kelsen tersebut untuk Austria tapi Mahkamah Konstitusi Cekoslowakia merupakan Mahkamah Konstitusi pertama yang dibentuk di dunia berdasarkan pemikiran Kelsen.
Perkembangan selanjutnya ketika ada negara yang mencoba menghembuskan gagasan tentang perlunya Mahkamah Konstitusi dalam negara itu untuk diberikan hak menguji, maka hal itu sering diistilahkan dengan istilah" the kelsenian model".

Istilah " the kelsenian model " pun tak dapat dibendung pada saat pembentukan Mahkamah Konstitusi di Indonesia. Gagasan pembentukan Mahkamah Konstitusi di Indonesia mulanya telah terintrodusir saat pembahasan UUD 1945 oleh BPUPK pada tahun 1945, salah satu anggota BPUPK Muhammad Yamin telah mengemukakan pendapat bahwa "Balai Agung" ( Mahkamah Agung ) perlu diberi kewenangan untuk membanding undang-undang. Namun, Soepomo menolak pendapat tersebut dengan beberapa alasan?

Selanjutnya kewenangan untuk melakukan pengujian Undang-undang terhadap UUD 1945 berada di tangan MPR. Kewenangan ini ditegaskan dalam Tap MPR Nomor III/MPR/2000 tentang Sumber Hukum dan Tata Urutan Peraturan Perundang-Undangan. Namun, karena pengujian ini dilakukan oleh MPR yang nyatanya merupakan lembaga yang membentuk UUD 1945, maka banyak terjadi perdebatan menyangkut dengan kewenangan tersebut. Dari kubu yang mempersoalkan kewenangan MPR tersebut mengemukakan bahwa sangat tidak dapat diterima jikalau MPR harus menguji kembali produk hukum yang dibuatnya sendiri. ${ }^{8}$

Kemudian pada saat pembahasan terhadap amandemen UUD 1945, setidaknya terdapat tiga pilihan menyangkut dengan lembaga yang berwenang menguji Undangundang terhadap UUD 1945, yaitu MPR, Mahkamah Konstitusi, dan Mahkamah Agung. Akhirnya kewenangan ini tidak lagi diberikan kepada MPR karena MPR pada saat itu bukan lagi sebagai lembaga tertinggi negara dan juga karena di MPR sangat

5. Ni'matul Huda dan Nazriyah, 2011, Teori Dan Pengujian Peraturan Perundang-Undangan, Bandung, Nusa Media, hlm 126.

6. id, hlm 3 .

7. Lihat Janedjri M. Gaffar, 2013, Hukum Pemilu Dalam Yurisprudensi Mahkamah Konstitusi, Jakarta, Konstitusi Press, hlm 7-8.

8. id, hlm 11. 
minimnya pakar hukum dan konstitusi. ${ }^{9}$

Ide untuk memberikan kewenangan tersebut kepada Mahkamah Agung pun menjadi tidak masuk akal karena nyatanya Mahkamah Agung masih mempunyai hutang perkara yang begitu banyak. Selain itu juga, dilihat dari sisi tugas dan kewenangan, maka sudah dapat dipastikan bahwa Mahkamah Agung sudah sangat sibuk dengan tugas dan kewenangannya yang begitu banyak, sehingga tak ayal lagi bahwa yang paling tepat untuk memangku kewenangan tersebut ialah Mahkamah Konstitusi yang merupakan suatu lembaga baru anak dari reformasi.

Sejalan dengan pembentukan Mahkamah Konstitusi, Soerjono Soekanto dan Sri Mamudji mengemukakan bahwa sesuai dengan prinsip negara hukum, maka setiap peraturan perundang-undangan harus berdasar dan bersumber dengan tegas pada peraturan perundang-undangan yang berlaku, yang lebih tinggi tingkatannya. ${ }^{10}$ Untuk itulah penulis juga meyakini diperlukan lembaga Mahkamah Konstitusi untuk menegakan peraturan perundang-undangan yang tidak sesuai dengan UUDNRI Tahun 1945 sebagai Konstitusi Indonesia.

Pembentukan Mahkamah Konstitusi di Indonesia juga tidak luput dari tanggapan salah satu begawan hukum Indonesia, Satjipto Rahardjo. Ia mengemukakan pendapat dalam salah satu bukunya bahwa : ${ }^{116}$ UUD 1945 telah mengamanatkan pembuatan sebuah MK sebagai satu-satunya yang boleh melakukan pengujian terhadap UUD. Bukan main! Mengerikan! Luar biasa! Tentunya para hakim MK juga manusia-manusia yang berkualitas luar biasa. Mereka adalah Sembilan orang diantara lebih dari 200 juta jiwa manusia Indonesia yang boleh, berhak, dan berwenang mengatakan apa yang dipikirkan dan dikehendaki oleh UUD."

\section{Kekuatan Putusan Mahkamah Konstitusi dalam Perkara Constitutional Review.}

Putusan Mahkamah Konstitusi sejak diucapkan di hadapan sidang yang terbuka untuk umum dapat mempunyai tiga kekuatan, yaitu : ${ }^{12}$

\section{Kekuatan mengikat}

Kekuatan mengikat putusan Mahkamah Konstitusi berbeda dengan pengadilan biasa, tidak hanya meliputi pihak-pihak yang berperkara, yaitu pemohon, pemerintah, DPR/DPD, ataupun pihak terkait yang diizinkan memasuki proses perkara, tetapi putusan tersebut juga mengikat bagi semua orang, lembaga negara, dan badan hukum dalam wilayah Republik Indonesia

Ini berlaku sebagai hukum sebagaimana hukum diciptakan pembuat undang-undang. Hakim Mahkamah Konstitusi dikatakan sebagai negative legislatoryang putusannya bersifat erga omnes, yang ditujukan pada semua orang.

\section{Kekuatan Pembuktian}

Pasal 60 Undang-Undang Mahakamah Konstitusi menentukan bahwa materi muatan ayat, pasal dan/atau bagian dalam undangundang yang telah diuji, tidak dapat dimohonkan untuk diuji kembali. Dengan demikian, adanya putusan Mahkamah yang telah menguji suatu Undang-undang merupakan alat bukti yang dapat digunakan bahwa telah diperoleh suatu kekuatan pasti (gezag van gevijsde)

Dikatakan kekuatan pasti atau gezag van gevijsde tersebut bisa bersifat negatif maupun positif. Kekuatan pasti suatu putusan secara negatif diartikan bahwa hakim tidak boleh lagi memutus perkara permohonan yang sebelumnya pernah diputus sebagaimana disebut dalam Pasal 60 Undang-Undang Mahkamah Konstitusi. Dalam hukum perdata hal demikian diartikan, hanya jika diajukan pihak yang sama dengan pokok perkara yang sama.

Kaitannya dengan perkara konstitusi yang putusannya bersifat erga omnes, maka permohonan pengujian yang menyangkut materi yang sama yang sudah pernah diputus

\footnotetext{
9. Titon Slamet Kurnia, Mahkamah Konstitusi Republik Indonesia Sang Penjaga Ham (the guardian of human rights), 2013, Bandung, PT. Alumni, hlm 18.

10. Soerjono Soekanto dan Sri Mamudji, 1995, Penelitian Hukum Normatif, Jakarta, PT.RajaGrafindo Persada, hlm 18. 11. Satjipto Rahardjo, 2010, Penegakan Hukum Progresif, Jakarta, Kompas, hlm 163.

12. Maruarar Siahaan, 2012, Hukum Acara Mahkamah Konstitusi Republik Indonesia, Jakarta, Sinar Grafik, hlm 214.
} 
tidak dapat lagi diajukan untuk diuji oleh siapa pun. Putusan Mahkamah Konstitusi yang telah berkekuatan hukum tetap demikian dapat digunakan sebagai alat bukti dengan kekuatan pasti secara positif bahwa apa yang telah diputus oleh hakim itu telah dianggap benar. Pembuktian sebaliknya tidak diperkenankan.

\section{Kekuatan Eksekutorial}

Sebagai satu perbuatan hukum pejabat negara yang dimaksudkan untuk mengakhiri sengketa yang akan meniadakan atau menciptakan hukum yang baru, maka tentu saja diharapkan bahwa putusan tersebut tidak hanya merupakan kata-kata mati di atas kertas.

Sebagai suatu putusan hakim, setiap orang setiap orang kemudian akan berbicara bagaimana pelaksanaannya dalam kenyataan. Akan tetapi sebagaimana telah disinggung di atas berbeda dengan putusan hakim biasa, maka suatu putusan yang telah mengikat para pihak dalam perkara perdata memberi hak kepada pihak yang dimenangkan untuk meminta putusan tersebut dieksekusi jikalau menyangkut penghukuman atas pihak yang kalah untuk melakukan sesuatu atau membayar sejumlah uang. Dalam hal demikian dikatakan bahwa putusan yang telah berkekuatan hukum tetap itu mempunyai kekuatan eksekutorial, yaitu agar putusan dilaksanakan dan jika perlu dengan kekuatan paksa.

Apakah putusan Mahkamah Konstitusi memiliki kekauatan eksekutorial demikian? Dalam satu jawaban atas pertanyaan pers, seorang menteri mengatakan bahwa benar hakim Mahkamah Konstitusi adalah legislator dan putusannya berlaku sebagai undangundang, tetapi tidak memerlukan perubahan yang harus dilakukan dengan amandemen atas undang-undang yang bagian tertentu dinyatakaan bertentangan dengan UUD 1945 dan tidak mempunyai kekuatan mengikat secara hukum.

Pendapat demikian mungkin benar, karena jika dieksekusi putusan Mahkamah Konstitusi telah dianggap terwujud denghan pengumuman putusan tersebut ke dalam Berita Negara sebagaimana diperintahkan
Pasal 57 Ayat (3) Undang-Undang Mahkamah Konstitusi. Akan tetapi, dalam kenyataannya mungkin lain dengan apa yang diharapkan melalui putusan pengujian suatu UndangUndang.

\section{B. Hasil dan Pembahasan}

\section{Kekuatan Mengikat Putusan Constitutional Review Mahkamah Konstitusi Terhadap Mahkamah Agung.}

Penulis sendiri sependapat dengan beberapa ahli hukum tata negara bahwa putusan Mahkamah Konstitusi dalam perkara constitutional review harus selalu mempunyai kekuatan mengikat bagi Mahkamah Agung. Apapun alasan yang digunakan oleh Mahkamah Agung tetap saja tidak dapat menjustifikasi tindakan lembaga yang disebut terakhir itu untuk mengesampingkan putusan constitutional review Mahkamah Konstitusi. Setidaknya terdapat beberapa perspektif yang menjadi alasan pembenar setiap putusan constitutional review Mahkamah Konstitusi mempunyai kekuatan mengikat bagi Mahkamah Agung, yaitu :

a. Perspektif historis

Sejarah setidaknya mencatat bahwa Mahkamah Konstitusi adalah salah satu lembaga tuntutan reformasi. Lahir dari perdebatan yang panjang di DPR pada saat rapat pembahasan perubahan UUD 1945.Tulisan Moh Mahfud MD di Jurnal Sintesis, edisi Mei-Juni 1999 mengemukakan 7 (tujuh) usulan materi perubahan UUD 1945. Salah satu usulan ialah pemandirian dan perluasan hak MA termasuk hak melakukan judicial reviewatas undang-undang dan semua peraturan perundang-undangan yang berada di bawahnya. Namun, apabila hak itu membebani MA, dapat dibentuk MK.

Tulisan Mahfud ini kiranya memberikan kontribusi tersendiri bagi perkembangan hukum dan ketatanegaraan bangsa Indonesia pada kala itu. Begitu pentingnya judicial review itu sampai-sampai Ia menyatakan bahwa kalau itu membebani MA, dapat dibentuk MK. Setidaknya saran Beliau tersebut dapat dilihat sebagai alternatif yang cukup baik. 
Pada saat rapat pembahasan perubahan UUD 1945 di DPR awalnya terdapat tiga alternatif lembaga yaitu MPR atau MA atau MK. Pemberian kewenangan kepada MPR dipandang tidak lagi relevan karena MPR tidak lagi berkedudukan sebagai lembaga tertinggi serta anggota MPR bukan ahli hukum dan Konstitusi. Pemberian kewenangan kepada MA juga tidak disepakati karena MA sendiri mengaku sudah terlalu banyak beban tugas memeriksa dan memutus perkara yang menjadi kompetensinya. Akhirnya disepakati kewenangan pengujian UU terhadap UUD 1945 dilakukan oleh lembaga tersendiri, yaitu MK sebagai salah satu pelaku kekuasaan kehakiman, walaupun pada awalnya juga terdapat perdebatan mengenai kelembagaan MK apakah merupakan lembaga mandiri atau merupakan bagian dari lembaga lain. ${ }^{14}$

Berdasarkan uraian tentang urgensi pembentukan Mahkamah Konstitusi secara historis di atas, maka tentu saja setiap putusan dari lembaga Mahkamah Konstitusi tersebut harus mengikat seluruh subyek hukum termasuk Mahkamah Agung, sebab spirit dari pembentukan Mahkamah Konstitusi tersebut secara historis begitu kuat dalam kehidupan ketatanegaraan Indonesia pada saat lembaga tersebut menjadi salah satu isu dalam perubahan UUD 1945.

b. Perspektif objek yang dilindungi

Mahkamah Konstitusi sebagai suatu lembaga negara diberikan tugas yang sangat eksklusif. Lembaga ini bertugas menjaga dan melindungi UUDNRI Tahun 1945 sebagai Konstitusi Indonesia. Tugas dari Mahkamah Konstitusi tersebut setidaknya tercermin dalam berbagai kewenangannya. Kewenangan lembaga ini antara lain ${ }^{15}$ :"Mahkamah Konstitusi berwenang mengadili pada tingkat pertama dan terakhir yang putusannya bersifat final untuk menguji undang-undang terhadap Undang-Undang Dasar, memutus sengketa kewenangan lembaga negara yang kewenangannya diberikan oleh Undang-Undang Dasar,memutus pembubaran partai politik, dan memutus perselisihan tentang hasil pemilihan umum."

Berdasarkan rumusan kewenangan dari lembaga ini, maka jelas bahwa sebenarnya objek utama yang dilindungi oleh Mahkamah ini ialah UUDNRI Tahun 1945, oleh sebab itu, tidak ada alasan bagi Mahkamah Agung untuk tidak tunduk pada putusan Mahkamah Konstitusi dalam perkara constitutional review, karena sekali lagi objek yang dilindungi oleh Mahkamah Konstitusi ialah UUD 1945.

\section{c. PerspektifFungsional}

Ditinjau dari perspektif fungsional kelembagaan, maka benar saja Mahkamah Konstitusi dan Mahkamah Agung merupakan dua lembaga negara yang independen sebagai penyelenggara kekuasaan kehakiman. Hal ini dapat dilihat dalam Pasal 24 Ayat (2) UUD NRI Tahun 1945 hasil amandemen yang secara tegas menentukan bahwa :"Kekuasaan kehakiman dilakukan oleh sebuah Mahkamah Agung dan badan peradilan yang berada di bawahnya dalam lingkungan peradilan umum, lingkungan peradilan agama, lingkungan peradilan militer, lingkungan peradilan tata usaha negara dan oleh sebuah Mahkamah Konstitusi.”

Muncul pertanyaan "Apakah karena dua lembaga ini tidak terdapat hubungan hierarki, maka yang satu dapat mengesampingkan putusan yang lain?" Pertanyaan ini memang menarik untuk digali lebih jauh, sebab Mahkamah Agung dan Mahkamah Konstitusi merupakan dua lembaga negara yang independen.

Hematpeneliti walaupun kedua lembaga tersebut independen ketika memutuskan perkara yang diajukan kepadanya, namun tidak berarti bahwa putusan constitutional review Mahkamah Konstitusi dapat dikesampingkan oleh Mahkamah Agung. Justru karena dua lembaga ini merupakan lembaga-lembaga negara yang independen, maka yang satu tidak boleh mengesampingkan putusan dari yang lainnya, sebab ketika itu terjadi, dengan sendirinya inddependensi dari kedua lembaga tersebut

14. Muchamad Ali Safa'at dkk, 2010, Hukum Acara Mahkamah Konstitusi, Jakarta, Sekretariat Jendral dan Kepaniteraan Mahkamah Konstitusi RI, hlm 7.

15. Lihat Pasal 24C Ayat (1) UUD 1945 Hasil Amandemen. 
telah terganggu. Lagi pula keduanya merupakan penyelenggara kekuasaan kehakiman sehingga dengan sendirinya harus timbul sinergitas dalam menjalankan kewenangannya masing-masing.

Tindakan Mahkamah Agung yang tidak mengindahkan putusan Mahkamah Konstitusi tersebut merupakan tindakan yang justru tidak menjaga kemandirian kekuasaan kehakiman, sebab tindakan yang demikian tidak jauh berbeda dampaknya jikalau dilakukan oleh lembaga eksekutif maupun legislatif.

Oleh karenaitu, kembali peneliti tegaskan bahwa jikalau "independen" menjadi alasan untuk menjustifikasi putusan constitutional review Mahkamah Konstitusi tidak mempunyai kekuatan mengikat bagi Mahkamah Agung, maka alasan tersebut kurang tepat karena justru alasan independen itulah yang seharusnya membuat Makamah Agung tidak boleh mengesampingkan putusan Mahkamah Konstitusi.

\section{d. PerspektifNormatif}

Pasal 47 Undang-undang Mahkamah Konstitusi ditentukan secara tegas bahwa : "Putusan Mahkamah Konstitusi memperoleh kekuatan hukum tetap sejak selesai diucapkan dalam sidang pleno terbuka untuk umum." Membaca ketentuan ini, maka terang benderanglah bahwa putusan Mahkamah Konstitusi haruslah mengikat Mahkamah Agung, sebab putusan tersebut tidak dapat lagi dilakukan upaya hukum. Kalau suatu putusan Pengadilan sudah tidak dapat lagi dilakukan upaya hukum (Banding,Kasasi, dan PK) bukankah putusan tersebut langsung dapat dieksekusi? Seperi halnya putusan perkara pencurian sepeda motor yang terdakwanya divonis 3 tahun penjara oleh Majelis Hakim. Ketika putusan ini telah mempunyai kekuatan hukum tetap, maka Jaksa Penuntut Umum langsung dapat mengeksekusi putusan tersebut. Hal ini juga berlaku bagi putusan Mahkamah Konstitusi yang walaupun eksekusinya tidak memerlukan suatu aparat khusus, namun karena telah memperoleh kekuatan hukum tetap otomatis langsung mengikat umum. Selain itu juga dalam Pasal 53 Undang- undang yang sama ditentukan pula bahwa: "Mahkamah Konstitusi memberitahukan kepada Mahkamah Agung adanya permohonan pengujian undang-undang dalam jangka waktu paling lambat 7 (tujuh) hari kerja sejak permohonan dicatat dalam Buku Registrasi Perkara "Konstitusi"

Menurut hemat peneliti, jikalau mau membaca Pasal 53 ini secara seksama, maka akan diperoleh pemaknaan yang seragam, yaitu bahwa ketentuan ini bermaksud agar Mahkamah Agung dan badan peradilan di bawahnya dapat mengetahui bahwa pasal atau Undang-undang yang sedang digunakan untuk mengadili suatu perkara tengah dimohonkan untuk diuji di Mahkamah Konstitusi. Kemudian yang berikut ialah ketentuan Pasal 55 Undang-Undang Mahkamah Konstitusi yang menetapkan bahwa : "Pengujian peraturan perundangundangan di bawah undang-undang yang sedang dilakukan Mahkamah Agung wajib dihentikan apabila undang-undang yang menjadi dasar pengujian peraturan tersebut sedang dalam proses pengujian Mahkamah Konstitusi sampai ada putusan Mahkamah Konstitusi."

Pasal 55 ini sejatinya memberikan nuansa kepastian hukum dalam penanganan perkara judicial review oleh Mahkamah Agung. Pastinya akan sangat tidak efisien jikalau perkara tersebut harus dihentikan prosesnya karena Undang-undang yang menjadi landasan batu uji bagi Mahkamah Agung melakukan judicial review tersebut dibatalkan oleh Mahkamah Konstitusi. Mengatasi masalah ini, maka tepatlah jikalau pembentuk Undang-undang memanifestasikan rumusan kalimat dalam Pasal 55 dalam Undangundang Mahkamah Konstitusi.

Argumen peneliti bahwa proses perkara judicial review di Mahkamah Agung harus dihentikan apabila Undang-undang yang menjadi landasan batu uji dalam perkara itu dibatalkan oleh Mahkamah Konstitusi sangat didukung dengan ketentuan Pasal 58 UndangUndang Mahkamah Konstitusi yang menetapkan bahwa: "Undang-undang yang diuji oleh Mahkamah Konstitusi tetap

16. Lihat Pasal 53 Undang-Undang Nomor 24 Tahun 2003 tentang Mahkamah Konstitusi sebagaimana telah diubah dengan UndangUndang Nomor 8 Tahun 2011 tentang perubahan atas Undang-Undang Nomor 24 Tahun 2003 tentang Mahkamah Konstitusi. 
berlaku, sebelum ada putusan yang menyatakan bahwa undang-undang tersebut bertentangan dengan Undang- Undang Dasar Negara Republik Indonesia Tahun 1945." Berdasarkan ketentuan Pasal 58 ini, maka jelaslah bahwa Undang-undang Mahkamah Konstitusi telah didesain sedini mungkin untuk mengatasi kevakuman-kevakuman yang mungkin saja terjadi di kemudian hari. Oleh karenanya peneliti agak sedikit keberatan jikalau dikatakan bahwa Undangundang Mahkamah Konstitusi tidak mengatur secara rinci tentang eksekusi putusan Mahkamah Konstitusi dan juga berdasarkan ketentuan-ketentuan normatif ini, maka jelas bahwa putusan constitutional review Mahkamah Konstitusi mempunyai daya mengikat bagi Mahkamah Agung.

Hal lain yang juga menurut penulis sebagai penegasan bahwa putusan Mahkamah Konstitusi langsung berlaku ialah ketentuan yang terdapat di dalam Pasal 57 Ayat (3) Undang-Undang Nomor 24 Tahun 2003 tentang Mahkamah Konstitusi yang menentukan bahwa : "Putusan Mahkamah Konstitusi yang mengabulkan permohonan wajib dimuat dalam Berita Negara dalam jangka waktu paling lambat 30 (tiga puluh) hari kerja sejak putusan diucapkan."

Hemat peneliti, maksud pemuatan putusan Mahkamah Konstitusi di Berita Negara Republik Indonesia yang seperti itu ialah agar putusan tersebut dapat diketahui oleh khalayak ramai. Seperti halnya Undangundang yang pengundangannya dilakukan di dalam Lembaran Negara Republik Indonesia dan diumumkan dalam Berita Negara Republik Indonesia agar dapat diketahui pula oleh khalayak ramai.

Maria Farida Indrati Soeprapto mengemukakan bahwa bahwa suatu peraturan perundang-undangan yang sudah disahkan atau ditetapkan baru dapat berlaku mengikat umum apabila peraturan perundangundangan tersebut diundangkan dalam suatu Lembaran Negara atau diumumkan dalam suatu Berita Negara. ${ }^{17}$

Kalau Undang-undang saja langsung berlaku ketika dimuat dalam Lembaran
Negara Republik Indonesia dan Berita Negara Republik Indonesia, maka tentunya putusan Mahkamah Konstitusi juga demikian maksud filosofinya ketika dimuat di dalam Berita Negara Republik Indonesia. Lagi pula sifat dari undang-undang dan putusan Mahkamah Konstitusi itu ialah sama saja, yaitu mengikat umum (erga omnes).

\section{Simpulan dan Saran}

Berdasarkan uraian di atas, maka diperoleh kesimpulan bahwa putusan constitutional review Mahkamah Konstitusi mempunyai kekuatan mengikat bagi Mahkamah Agung didasarkan pada beberapa perspektif, yaitu :

1. Perspektifhistoris;

2. Perspektif objek yang dilindungi;

3. PerspektifFungsional; dan

4. Perspektif normatif

Berdasarkan simpulan di atas, maka dapat disampaikan saran sebagai berikut:

1. Pemerintah dan DPR harus segera memperkuat kekuatan mengikat putusan Mahkamah Konstitusi dalam perkara putusan constitutional review melalui revisi perundang-undangan terkait.

\section{DAFTAR PUSTAKA}

Ali Safa'at, Muchamad, dkk, 2010, Hukum Acara Mahkamah Konstitusi, Jakarta: Sekretariat Jendral dan Kepaniteraan Mahkamah Konstitusi RI.

Huda, Ni'matul dan Nazriyah, 2011, Teori Dan Pengujian Peraturan PerundangUndangan, Bandung: Nusa Media.

M. Gaffar, Janedjri , 2013, Hukum Pemilu Dalam Yurisprudensi Mahkamah Konstitusi, Jakarta: Konstitusi Press.

Slamet Kurnia, Titon, Mahkamah Konstitusi Republik Indonesia Sang Penjaga Ham (the guardian of human rights), 2013, Bandung: PT. Alumni.

MD Mahfud, Moh , 2010, Konstitusi Dan Hukum Dalam Kontroversi Isu, Jakarta, Rajawali Pers.

Rahardj, Satjipto, 2010, Penegakan Hukum Progresif, Jakarta: Kompas.

Siahaan, Maruarar 2012 Hukum Acara

16. Maria Farida Indrati Soeprapto, 1998, Ilmu Perundang-Undangan, Dasar-dasar dan pembentukannya, Yogyakarta, Kanisius, h $\operatorname{lm} 176$. 
MMH, Jilid 44 No. 4, Oktober 2015

Mahkamah Konstitusi Republik Indonesia, Jakarta: Sinar Grafika.

Soekanto, Soerjono dan Mamudji, Sri 1995, Penelitian Hukum Normatif, Jakarta: PT.RajaGrafindo Persada.

Soeprapto Indrati, Maria Farida, 1998, Ilmu Perundang-Undangan, Dasar-dasar dan pembentukannya, Yogyakarta: Kanisius.

Subekti, R, 1980, Kekuasaan Mahkamah Agung RI, Bandung: Alumni.

\section{Website:}

http://news.detik.com/read/2014/09/26/0846 23/2701838/158/1/kasus-dr-bambangmantan-ketua-mk-emangnya-artidjo-pastibaik, diakses pada tanggal 02 Maret 2015. 